\title{
The Continuing Relevance of the Marxist Tradition for Transcending Capitalism
}

\author{
Erik Olin Wright
}

University of Wisconsin, Department of Sociology, Madison, USA, City, Country, eowright@wisc.edu, http://www.ssc.wisc.edu/ wright

\begin{abstract}
No idea is more closely associated with Marx than the claim that the intrinsic, contradictory dynamics of capitalism ultimately lead to its self-destruction while simultaneously creating conditions favourable for a revolutionary rupture needed to create an emancipatory alternative in which the control by the capitalist class of investments and production is displaced by radical economic democracy. Marx's formulation of a theory of transcending capitalism is unsatisfactory for two main reasons: 1) the dynamics of capitalism may generate great harms, but they do not inherently make capitalism unsustainable nor do they generate the structural foundations of a collective actor with a capacity to overthrow capitalism; 2) the vision of a system-level rupture with capitalism is not a plausible strategy replacing capitalism by a democratic-egalitarian economic system. Nevertheless, there are four central propositions anchored in the Marxist tradition that remain essential for understanding the possibility of transcending capitalism: 1. Capitalism obstructs the realization of conditions for human flourishing. 2. Another world is possible. 3. Capitalism's dynamics are intrinsically contradictory. 4. Emancipatory transformation requires popular mobilization and struggle. These four propositions can underwrite a strategic vision of eroding the dominance of capitalism by building democratic-egalitarian economic relations within the contradictory spaces of capitalism.
\end{abstract}

Keywords: Karl Marx, 200th anniversary, transcendence of capitalism, real utopias, socialism, contradiction, crisis

Acknowledgement: Some of the passages in this essay are modified from Erik Olin Wright, Envisioning Real Utopias (Verso 2010) and How to be an Anticapitalist for the 21st Century (unpublished manuscript, 2018). A condensed version of this essay appears in Global Dialogue, March 2018 (http://isa-global-dialogue.net/).

\section{Marx's Argument}

No idea is more closely associated with Marx than the claim that the intrinsic dynamics of capitalism contain deep contradictions that ultimately lead to its selfdestruction, and what's more, these dynamics simultaneously create conditions favourable for a revolutionary rupture needed to create a new form of society much more conducive to human flourishing. The first part of the argument constitutes a strong prediction about the destiny of capitalism: In the long-term, capitalism is an unsustainable social order and will inevitably come to an end. This is a much stronger claim than simply that capitalism generates harms of various sorts and suffers from periodic crises. It is a prediction that capitalism ultimately destroys itself. The second part is somewhat less deterministic: The dynamics that destroy capitalism open up new historic possibilities (especially because of the development of the forces of production and human productivity) and, at the same time, create a collective agent - the working class - capable of taking advantage of those possibilities to con- 
struct an emancipatory alternative through revolution. How long it will take before this latent capability will actually result in the realization of this alternative, and precisely what the alternative will look like, depends on range of more contingent processes: the dissemination of revolutionary ideology, the emergence of robust solidarities, the development of forms of political organisation able to give coherence to struggles, and so on. Taken as a whole, therefore, the theory embodies an interplay of deterministic claims about the inevitable self-destructive demise of capitalism and the emergence of favourable structural conditions for revolution with less deterministic claims about the timing and institutional design of an emancipatory future beyond capitalism. ${ }^{1}$

This duality of deterministic and nondeterministic claims is part of what made Marx's theoretical ideas such a compelling basis for political movements. The nondeterministic elements validate the importance of purpose-filled collective agency and the willingness of individuals to join in the struggle for a better world. The deterministic elements give reasons for optimism: Even when the obstacles to revolution seem daunting, anti-capitalist forces could believe that 'history is on our side' and eventually the conditions will be 'ripe' for a revolutionary break-through.

\section{The World Today}

We now live in a world very different from the one in which Marx formulated his theoretical ideas, and it is difficult to sustain the exuberant optimism of Marx's theory of the future beyond capitalism. Two issues are especially salient.

First, some of the key empirical predictions, crucial for the overarching aspiration for transcending capitalism, have not been born out: Rather than becoming steadily more homogeneous, the working class has become increasingly fragmented, internally unequal, and heterogeneous in all sorts of ways, impeding the broad class solidarity needed for sustained collective action against capitalism; capitalism has proven much more resilient in responding to crises with new modes of accumulation; the capitalist state has proven much more flexible in absorbing popular demands and counteracting crises, while resorting to effective repression when needed; the material standards of living of most people in developed capitalist societies and many in poorer regions of the world, have continued to rise, even during the recent decades of relative economic stagnation. ${ }^{2}$ Other predictions of Marx, of course, have been

\footnotetext{
1 There is a longstanding debate within the Marxist tradition over how deterministic Marx himself was about the destiny of capitalism. There is no ambiguity in his views that the contradictions of capitalism would necessarily destroy its conditions of existence. His model of capitalism contains no prediction about how rapidly this will occur, but it is clear about the ultimate demise of the system. I believe that in his major writing, Marx was also prepared to make strong predictions about the destiny beyond capitalism: Once the structural conditions favourable to a rupture are present, eventually a revolutionary break-through would occur. The precise timing was contingent on ideological and political processes, but not the ultimate outcome. Rosa Luxemburg is famous for saying that the choices facing humanity were "socialism or barbarism", which implies that an emancipatory future beyond capitalism is not inevitable even in the long run; barbarism is also a possibility. Marx did not express such ambiguity. In any case, regardless of Marx's own views on this, many people who identify with the Marxist tradition today adopt a much less deterministic view about the overall trajectory of capitalism and especially about the possibilities and prospects after capitalism.

2 This last point is worth emphasizing. While it is true that real wages have been relatively stagnant for the median wage-earner in many rich countries since the early 1980s, never-
} 
spot on: Capitalism has become a global system, reaching the far corners of the world; the forces of production have developed in astonishing ways, tremendously increasing human productivity; capitalist markets deeply penetrate most facets of life; economic crises, sometimes severe, are a persistent feature of capitalist societies. The problem is that none of these trends are central to the core prediction that capitalism necessarily destroys its own conditions of existence while simultaneously creating an historical subject capable of its overthrow. These dual linked propositions have lost credibility.

Some people argue that new crisis tendencies unforeseen by Marx, especially catastrophic climate change, may make capitalism not simply undesirable, but unsustainable. Of course, if, as some environmentalists claim, global warming will ultimately make human life impossible, capitalism would also be impossible. But short of such apocalyptic outcomes, it is not obvious that climate change poses a mortal threat to capitalism as such. The terrible effects of capitalism on the environment are one important reason to oppose capitalism, but the irrationality and undesirability of capitalism do not imply its unsustainability. Climate change is like war: Just as war is often good for capitalism because of the role of the state in assuring capitalist profits in war industries, there is a huge amount of money to be made out of the massive public works projects needed for climate adaptation. Climate change may threaten the specific neoliberal form of capitalism, but it is much less clear that in and of itself it renders capitalism as such unsustainable. Furthermore, unlike the specific dynamics proposed by Marx, even if the climate crisis made capitalism unsustainable, it does not simultaneously create favourable conditions for the powerful, cohesive forms of solidarity needed for an emancipatory overthrow capitalism; it generates no latent "historical subject" comparable to Marx's vision of the proletariat. ${ }^{3}$

The second reason why Marx's optimistic vision has lost credibility is the tragic history in the 20th century of the attempts at constructing an alternative to capitalism in the aftermath of socialist revolutions. It is very difficult to have confidence that even if crises create the opportunity for revolutionary political forces to seize power, that they will have the capacity to actually construct an emancipatory alternative.

Marx himself never gave much attention to the problem of either the design of socialism, or to the actual process through which it would be constructed. Basically, he

theless the material standards of living - the bundle of what people actually consume - of the median household have risen on virtually every indicator over the past four decades. Some of this is due to the increase in labour force participation of women, but much of it is due to significant improvements in the quality of many products and the availability of cheap mass produced consumer goods. Inequality has increased dramatically, but this has gone along with modest improvements in median living standards.

${ }^{3}$ There are other arguments people make to support the proposition that the endogenous dynamics of capitalism ultimately destroy its conditions of possibility, in particular, capitalism needs endless growth, but endless growth is impossible (Harvey 2014, chapter 15), or the rapid acceleration of automation will ultimately destroy the conditions of profitability for capitalist firms (Mason 2016, Rifkin 2014). I do not have space in this essay to explore these arguments, but briefly: (1) Growth: Capitalist investment and competition do foster growth, but this does not inherently imply a growth in physical output, nor does it imply that across the cycles of growth and decline there must be net growth overtime. (2) Automation: The idea that automation will destroy capitalism depends on a specific use of the Labour Theory of Value in which only labour generates value and only surplus labour in the form of surplus value generates profits. If one rejects the LTV, then there is no reason to believe that high levels of automation necessarily undermine system-level profits. 
felt that given his prediction of the conditions under which this task would be undertaken - the decay of capitalism, the emergence of a powerful, extensive working class, and the existence of a class conscious revolutionary movement - the creative forces of the collectively organized working class would figure this out through a process of experimental trial-and-error. The experience of the 20th century does not provide much evidence to support this expectation.

Why the revolutions of the 20th century never resulted in robust, sustainable human emancipation is, of course, a hotly debated matter. Was this simply because of the economic backwardness of the places where revolutions occurred, or strategic errors or problematic motivations of leadership? Or do the repeated failures to build sustainable emancipatory alternatives through attempts at radical ruptures in social systems reflect the impossibility of the task? Perhaps attempts at system-ruptures will inevitably unravel into such chaos that revolutionary parties, regardless of the motives of their leadership, will be compelled to resort to pervasive violence and repression to sustain social order, and such violence, in turn, destroys the possibility for a genuinely democratic, egalitarian process of building a new society. The unintended negative consequences of what it takes to carry out a system-rupture may overwhelm the intended emancipatory goals. Regardless of which (if any) of these explanations are correct, the evidence from the revolutionary tragedies of the 20th century is that system-level rupture doesn't work as a strategy for social emancipation. ${ }^{4}$

\section{The Robust Anchors for Continuing a Marxist Theory of Transcending Capital- ism}

In the 21st century, therefore, it is no longer plausible to see the "laws of motion of capitalism" as inevitably destroying the viability of capitalism while simultaneously creating favourable conditions for its emancipatory transcendence through a revolutionary rupture. This does not mean, however, that the Marxist tradition has lost its relevance for both the scientific understanding of contemporary society and the efforts to create a better world. In particular, four central propositions, firmly anchored in the Marxist tradition, remain essential:

\section{Proposition 1. Capitalism obstructs the realisation of conditions for human flourishing.}

The sharpest indicator of this is persistent poverty in the midst of plenty, but the harms of capitalism extend beyond material deprivation to other values important for human flourishing: equality, democracy, freedom, and community. The source of these harms of capitalism is above all its class structure, understood as the power relations through which investment, production, and distribution are organised. The class relations of capitalism create harms through a variety of familiar mechanisms: exploitation; domination; alienation; the conversion of economic power into political power; destructive forms of competition; the expansion of markets in ways that undermine community and reciprocity. ${ }^{5}$ The harms embodied in these processes can be

4 This, of course, does not prove that a ruptural strategy for system-level transformation could never work at some time in the future, but currently there are no theoretical arguments sufficiently compelling to neutralize the empirical evidence from past failures.

${ }^{5}$ Many writers in the Marxist tradition also argue that the harms of capitalism are generated by markets as a mechanism of economic coordination. Michael Albert and Robin Hahnel, for example, in their various writing on participatory economics, argue that not only must the class relations of capitalism be transformed, but that markets must be eliminated if social emancipation is to occur in a sustainable fashion. In contrast, I argue that the harms of 
amplified or moderated by various countervailing processes, especially organised through the state; but it nevertheless remains the case that capitalist class relations continually generate harmful effects.

\section{Proposition 2. Another world is possible.}

The harms generated by capitalism provide ample grounds for resistance to capitalism and for the desire for an alternative. By themselves, however, harms do not demonstrate that an alternative to capitalism is actually possible.

The theoretical argument that another world is in fact possible is perhaps the most fundamental idea of the Marxist tradition: An emancipatory alternative to capitalism, in which the control by the capitalist class of investments and production is displaced by radical economic democracy, is realisable. ${ }^{6}$ Marxists are not alone in identifying harms generated by the ramifications of capitalism and its class relations. Indeed, many of the relevant mechanisms identified within the Marxist tradition have been incorporated into non-Marxist social science. What is distinctive to the Marxist tradition is the argument that a fundamental alternative to capitalism is not simply desirable, but also viable and achievable. This is what changes Marxism from simply a critique of capitalism into an emancipatory social science.

Of particular importance in the Marxist tradition is the idea that the development of the forces of production within capitalism opens up new possibilities for human flourishing which are blocked by the continuing dominance of capitalist relations of production. The advances in human productivity make it possible, under suitable social relations of production, to drastically reduce the amount of time people need to spend producing their means of livelihood, thus expanding what Marx (1981/1894, 958-959) called "the realm of freedom". This liberation of human activity, however, can only occur if capitalism is replaced by socialism, understood as a democratic, egalitarian, solidaristic organisation of the economy.

\section{Proposition 3. Capitalism's dynamics are intrinsically contradictory.}

Capitalism cannot achieve a stable equilibrium in which everything fits together into a coherent, functionally integrated whole. Even if there is no inherent tendency for capitalist contradictions to reach an intensity to make capitalism unsustainable, they repeatedly destabilise and undermine existing institutional configurations. In particular, the relationship between capital accumulation and the state is always fraught with contradictions. The state continually faces incompatible imperatives for reproducing capitalism: There are inconsistencies between what is optimal in the short-run and the long-run; between what is best for different sectors of capital; between the imperatives for social peace and capital accumulation. Sometimes these inconsistencies are pretty well managed, but forms of state regulation and intervention which stabilise

markets in capitalism come from the distinct form of capitalist markets, and that even in a democratic-egalitarian economy, markets will almost certainly play an important role. For a debate between Robin Hahnel's views and my own, see Hahnel and Wright (2016).

${ }^{6}$ Marx himself did not frame the idea of socialism as radical economic democracy, but this is basically what it means to say that the working class collectively controls the means of production. There are many possible institutional forms through which this idea could be realised, but the heart of the matter is a democratic-egalitarian structure of power over the economy. 
capitalism in one period often become obstacles to accumulation in another and institutional lock-in makes smooth adjustments impossible. The result is periodic crises, which open spaces for new possibilities and transformative struggles.

\section{Proposition 4. Emancipatory transformation requires popular mobilisation and strug- gle.}

The realisation of emancipatory possibilities requires collective action and mobilisation from below. Struggles are ultimately over power, and these inevitably involve confrontation. While positive class compromises ${ }^{7}$ may be one of the outcomes of struggle, such compromises will only become part of a larger project of social transformation when they are backed by robust popular mobilisation. For such compromises to occur, elite allies may be crucial, but emancipatory social transformation will not simply be the result of the initiatives of enlightened elites.

Emancipatory transformation also requires building new institutions that embody the emancipatory ideals, and these too must be grounded in the collective organisation and initiative of the masses. The social emancipation of the masses must, at its core, be the self-emancipation of the masses. There may be a constructive role for "social engineering" from above guided by experts, but in a sustainable process of emancipatory social transformation, such social engineering must itself be democratically subordinated through effective mechanisms of popular empowerment.

\section{A Strategic Logic of Transcending Capitalism for the 21st Century}

The four propositions above have a pedigree that can be traced back to Marx. They constitute fundamental parameters of the on-going Marxist tradition with which virtually everyone who describes their views as "Marxist" would almost certainly agree. ${ }^{8}$ They are not, however, sufficient to formulate a strategic vision for transcending capitalism in the 21st century. Here I will focus on one specific additional theoretical argument which I think is critical for understanding the possibility of a future beyond capitalism.

Every process of social transformation involves the interaction of two kinds of social change: social changes that occur "behind the backs" of people as the cumulative, unintended consequences of their actions, and social changes that are the intentional result of conscious strategy. In Marx's original theoretical formulation, conscious, strategic action for emancipatory transformation was mainly important in two contexts: First, in creating the necessary political organisation and forms of consciousness of the masses needed to overcome capitalism when conditions made this possible; and second, accomplishing the arduous task of constructing the new society after the revolutionary seizure of power. Constructing socialism for Marx would certainly require sustained conscious action, with a continual process of learning-bydoing and experimentation. Viable socialist institutions could not simply be the unintended by-product of the actions of revolutionaries. But Marx did not see conscious strategy as playing an important role in creating the underlying structural conditions

\footnotetext{
7 The term "positive" class compromise identifies a situation in which a compromise is not simply the result of a balance of forces (a "negative class compromise"), but embodies real solutions to problems within capitalism that also contribute to consolidating popular power. For an extended discussion of positive class compromise, see Wright (2015, chapter 11).

8 These propositions are particularly important for understanding the possibilities of transcending capitalism, but there may be other propositions which could legitimately be considered essential elements of the Marxist tradition for other purposes.
} 
needed for a revolutionary rupture in the first place. Those conditions include the massive development of the forces of production; the homogenisation of the conditions of life of the working class; the falling rate of profit; the increasing social character of production as the scale of organisation and division of labour increases. None of these are the result of a conscious strategy to create the needed conditions for emancipatory transformation; they are the result of the "laws of motion" of capitalism which propelled it along a trajectory which would eventually make capitalism vulnerable to overthrow. For Marx, although the structural conditions that make possible emancipatory transformation are the cumulative side-effect of human actions, they are not primarily the result of conscious strategy to create those conditions.

Marx was certainly correct in understanding history as the interplay of structural conditions and conscious strategy, but I do not think the particular sequencing implicit in his theory of the revolutionary transcendence of capitalism is adequate. Specifically, if, as I have argued, a ruptural strategy for transcending capitalism is not plausible, then if radical economic democracy is to be a future beyond capitalism, the task of consciously building it through strategic action needs to begin inside of capitalism itself. This requires going beyond Marx's view that capitalism becomes increasingly "social" in character as an unintended by-product of the laws of motion of capitalism. It requires a different understanding of the potential for strategies to deliberately affect the functioning and trajectory of existing economic systems by building the alternative to capitalism within economic systems still dominated by capitalism.

To understand the issues in play here, it will be helpful to begin with a stylised contrast between two ways of understanding the idea of a social "system". One metaphor for understanding a system is that of an organism. An organism is an integrated system in which all of the parts functionally fit together into a coherent whole. An organism is a "totality". Another metaphor for a system is an ecosystem. Think of a lake. A lake consists of water in a landscape, with particular kinds of soil, terrain, water sources and climate. An array of fish and other creatures live in its water and various kinds of plants grow in and around it. Collectively, these constitute the natural ecosystem of the lake. This is a "system" in that everything affects everything else within it, but it is not like the system of a single organism in which all of the parts are functionally connected in a coherent, tightly integrated whole. Social systems, in general, are better thought of as ecosystems of loosely connected interacting parts rather than as organisms - tightly integrated totalities - in which all of the parts serve a function.

Now consider capitalism. No economy has ever been - or ever could be - purely capitalist. Capitalism is defined by the combination of market exchange with private ownership of the means of production and the employment of wage-earners recruited through a labour market. Existing economic ecosystems combine capitalism with a whole host of other ways of organising the production and distribution of goods and services: directly by states; within the intimate relations of families to meet the needs of its members; through community-based networks and organisations in what is often called the social and solidarity economy; by cooperatives owned and governed democratically by their members; though non-profit market-oriented organisations; through peer-to-peer networks engaged in collaborative production processes; and many other possibilities. Some of these ways of organising economic activities can be thought of as hybrids, combining capitalist and non-capitalist elements; some are entirely non-capitalist; and some embody democratic-egalitarian-solidaristic principles that prefigure an emancipatory alternative to capitalism. Some of these noncapitalist forms are functionally hitched to capitalism, and in one way or another con- 
tribute to the stability of capitalism; others are in tension with capitalism; and some are both functional for and in tension with capitalism. We call such a complex economic ecosystem "capitalist" when it is the case that capitalism is dominant in determining the economic conditions of life and access to livelihood for most people. In a parallel manner, a socialist economy is an economic ecosystem in which democraticegalitarian relations are dominant.

Marx certainly recognised that real societies were never purely capitalist, and contained a variety of non-capitalist economic forms, especially vestiges from earlier modes of production. He even acknowledged that some of these non-capitalist forms could be thought of as prefiguring a future socialist economy. In particular, by the 1860 s he came to appreciate the anti-capitalist character of worker cooperatives. The virtue of these experiments, for Marx, were primarily ideological: "By deed instead of by argument, they have shown that production on a large scale, and in accord with the behests of modern science, may be carried on without the existence of a class of masters employing a class of hands" (Marx 1962/1864, 383). Cooperatives thus contributed to creating the ideological conditions for challenging capitalism, but Marx did not see them as part of a strategy of actually building a more democratic, egalitarian economy within a system that was still dominated by capitalism.

The strategic problem, then, is whether or not it is possible erode the dominance of capitalism within this complex economic ecosystem by expanding the weight of alternative, non-capitalist economic activities organized through democraticegalitarian-solidaristic relations. This way of thinking about the process of transcending capitalism is in certain respects like the typical stylised story told about the transition from pre-capitalist feudal societies in Europe to capitalism. Within feudal economies in the late medieval period, proto-capitalist relations and practices emerged, especially in the cities. Initially this involved merchant trading, artisanal production under the regulation of guilds, and banking. These forms of economic activity filled niches and were often quite useful for feudal elites. As the scope of these market activities expanded they gradually became more capitalist in character and, in some places, more corrosive of the established feudal domination of the economy as a whole. Through a long, meandering process over several centuries, feudal structures ceased to dominate the economic life of some corners of Europe; feudalism had eroded. This process may have been punctuated by political upheavals and even revolutions, but rather than constituting the basis for a rupture in economic structures, these political events generally served more to ratify and rationalise changes that had already taken place within the socioeconomic structure.

Of course, the process of transcending capitalism, if it were to happen, would not be a recapitulation of the process through which feudalism was eroded and eventually superseded by capitalism. In particular, eroding feudalism was not a strategy of proto-capitalist merchants, but rather a long-term unintended consequence of their profit-making practices. Strategy would have to play a significant role in eroding the dominance of capitalism and displacing it by a radical economic democracy. Here is the basic scenario:

Economic activities organised around democratic-egalitarian relations emerge where this is possible within an economy dominated by capitalism. These activities grow over time, both spontaneously and as a result of deliberate strategy. Some of these emerge as adaptations and initiatives from below within communities. Others are actively organised by the state to solve practical problems, either in the form of the direct state provision of goods and services as in classic state sector production, or in the form of state-funded collaborations with civil society organizations. These 
alternative economic relations constitute the building blocks of an economic structure whose relations of production are, to a variable degree, characterised by democracy, equality, and solidarity. I have referred to these building blocks as real utopias: "Utopias" insofar as they embody emancipatory ideals and aspirations; "real" insofar as they can be built in the world as it is in order to push it towards a world that could be ${ }^{9}$ (Wright 2010). Struggles involving the state take place, sometimes to protect these spaces, other times to facilitate new possibilities. Periodically what seems to be structural "limits of possibility" are encountered, and to go beyond such limits may require more intense political mobilisation directed at changing critical features of the "rules of the game" within which capitalism functions. Often such mobilisations fail, but at least sometimes political conditions allow for such changes, and the limits of possibility expand. Eventually, the cumulative effect of this interplay between changes from above and initiatives from below may reach a point where the democratic, non-capitalist relations created within the economic ecosystem become sufficiently prominent in the lives of individuals and communities that capitalism can no longer be said to dominate the system as a whole. ${ }^{10}$

As a strategic vision, eroding capitalism is both enticing and far-fetched. It is enticing because it suggests that even when the state seems quite uncongenial for advances in social justice and emancipatory social change, there is still much that can be done. We can get on with the business of building a new world within the interstices of the old. It is far-fetched because it seems implausible that the accumulation of emancipatory economic spaces within an economy dominated by capitalism could ever really erode and displace capitalism, given the immense power and wealth of large capitalist corporations and the dependency of most people's livelihoods on the well-functioning of the capitalist market. Surely if non-capitalist emancipatory forms of economic activities and relations ever grew to the point of threatening the dominance of capitalism, they would simply be crushed.

There are thus reasons to be sceptical. Two issues are particularly vexing. First, there is the problem of the state. The idea of eroding capitalism depends in significant ways on initiatives by the state. But the state in capitalist society is not simply a neutral apparatus that can be readily used by social forces opposed to capitalism. It is a particular kind of state - a capitalist state - designed in such a way as to systematically protect capitalism from threats. Eroding capitalism, therefore, is only possible if, in spite of the in-built class biases of the capitalist state, it is nevertheless possible use the state to facilitate the expansion of emancipatory non-capitalist rela-

\footnotetext{
${ }^{9}$ The idea of real utopias is not restricted to emancipatory aspirations for alternatives to capitalism. Real utopias include constructing alternative institutions for the state and democracy, the family and gender relations, community and cultural identity, and any other aspect of social relations which generate obstacles to human flourishing

10 This strategic vision for a future beyond capitalism bears a certain affinity to Gramscian arguments about the conditions for struggle against a hegemonic capitalist system. Gramsci argued that in capitalist societies with strong civil societies and effective states, it was impossible to seize power through a "war of manoeuvre." What was needed was a "war of position" to build a coherent, mobilised counter-hegemony in civil society. The idea of building economic institutions organised through democratic-egalitarian relations within an economic system dominated by capitalism is parallel to the idea of a counter-hegemonic "war of position." The difference is that Gramsci still saw the war of position as the prelude to an eventual war of maneuver in which a revolutionary seizure of power would occur and make possible a system-level rupture. The scenario presented here does not presuppose a culminating rupture.
} 
tions that point beyond capitalism. The fact that the capitalist state is not an instrument ideally suited to the erosion of capitalism does not mean it cannot be used imperfectly for that purpose. The trick for anti-capitalist political forces is to exploit the internal contradictions within the state and the contradictions it faces in solving problems within capitalism in order to expand the possibilities for creating democratic, egalitarian, solidaristic economic alternatives. A key to this possibility is the quality of democracy within the capitalist state: The more deeply democratic is the capitalist state, the greater the possibility of state policies supporting the conditions for noncapitalist alternatives. Struggles to "democratize democracy" - to use an expression of the Portuguese sociologist, Boaventura Santos (2007) - are thus pivotal to the prospects for eroding capitalism.

However, for the capitalist state to be used even imperfectly in a strategy to erode capitalism, there must be political forces mobilized to use it for these purposes. Eroding capitalism, like any strategy, needs collective actors. Strategies don't just happen; they are adopted by people in organizations, parties, and movements. This is the second vexing issue. Where are the collective actors for eroding capitalism? In classical Marxism "the working class" was seen as the collective actor capable of challenging capitalism. Few people today see the working class as sufficiently homogeneous to readily become what used to be called the "Subject of history". Rather, the formation of a politically coherent collective actor for a potent anti-capitalism of the 21st century will require bringing together people from a much more heterogeneous set of structural locations in the economy and society, with much more diverse identities. Class remains at the centre of such collective action, since, after all, the objective of struggle is the transformation of the class structure; this is what eroding capitalism means. But the political identity of the collective actor must be forged around the values of democracy, equality and solidarity rather than simply class as such, and this means constructing such a collective actor with people from a much more heterogeneous set of locations in the social structure. This is a daunting task. Figuring out how to do it is a central problem for the Left in the world today.

\section{References}

Hahnel, Robin and Erik Olin Wright. 2016. Alternatives to Capitalism: Proposals for a Democratic Economy. London and New York: Verso.

Harvey, David. 2014. Seventeen Contradictions and the End of Capitalism. Oxford: Oxford University Press.

Marx, Karl. 1981/1894. Capital: Volume III. London: Penguin.

Marx, Karl. 1962/1864. The Inaugural Address to the International Working Men's Associations. In Karl Marx and Frederick Engels, Selected Works in Two Volumes, Volume I, 342349. Moscow: Foreign Languages Publishing House.

Mason, Paul. 2016. Post-Capitalism: A Guide to our Future. New York: Farrar, Straus and Girioux.

Rifkin, Jeremy. 2014. The Zero Marginal Cost Society. New York: Palgrave MacMillan

Santos, Boaventura, ed. 2007. Democratizing Democracy: Beyond the Liberal Democratic Cannon. London and New York: Verso.

Wright, Erik Olin. 2010. Envisioning Real Utopias. London and New York: Verso.

Wright, Erik Olin. 2015. Understanding Class. New York and London: Verso.

\section{About the Author}

\section{Erik Olin Wright}

Erik Olin Wright is a leading sociologist and Vilas Distinguished Professor of Sociology at the University of Wisconsin. He is the author of many books, including Class, Crisis, and the 
State (1978), Class Structure and Income Determination (1979), The Debate on Classes (1989), Classes (1985/1997), Interrogating Inequality (1994), Class Counts (1997), Deepening Democracy (with Archon Fung, 2003), Approaches to Class Analysis (ed., 2005), Envisioning Real Utopias (2010), Understanding Class (2015), Alternatives to Capitalism: Proposals for a Democratic Economy (with Robin Hahnel, 2016)

https://www.ssc.wisc.edu/ wright/

https://en.wikipedia.org/wiki/Erik Olin Wright 